\title{
Breastfeeding: what do women who participate in a prenatal group think?
}

\author{
Amamentação: o que pensam as mulheres participantes de um grupo de pré-natal? \\ Lactancia: ¿qué piensan las mujeres que participan en un grupo de prenatal?
}

\section{Ana Emília Meneses Bezerra' ORCID: 0000-0002-0218-2552 \\ Luiz Henrique Carvalho Batista' ORCID: 0000-0003-3249-145X \\ Renata Guerda de Araújo Santos' ORCID: 0000-0003-0682-8880}

'Centro Universitário Cesmac. Maceió, Alagoas, Brazil.

How to cite this article:

Bezerra AEM, Batista LHC, Santos RGA. Breastfeeding: what do women who participate in a prenatal group think?. Rev Bras Enferm. 2020;73(3):e20180338. doi: http://dx.doi.org/10.1590/0034-7167-2018-0338

Corresponding author:

Renata Guerda de Araújo Santos

E-mail: guerdapsial@gmail.com

EDITOR IN CHIEF: Dulce Aparecida Barbosa ASSOCIATE EDITOR: Maria Saraiva

Submission: 05-13-2018

Approval: $07-21-2019$

\begin{abstract}
Objectives: to understand breastfeeding meanings and practices produced by women attending prenatal care at a Basic Health Unit in the Brazilian Northeast. Methods: a social research characterized as participant research. A Focal Group was conducted with nine pregnant women who had other children. For the analysis, Discursive Practices and Production of Meanings in Everyday Life perspectives were worked out. Results: prenatal care, mother-baby relationship, family, and pain/suffering categories were produced. Final Considerations: breastfeeding benefits for the child, wife, family and society are numerous, but it is necessary for the woman to have access to a prenatal care and a qualified puerperium so that she feels supported by a perspective of comprehensive care. Descriptors: Women's Health; Breastfeeding; Primary Health Care; Prenatal Care; Health Education.
\end{abstract}

\section{RESUMO}

Objetivos: compreender os sentidos e as práticas sobre a amamentação produzidos pelas mulheres acompanhadas no pré-natal em uma Unidade Básica de Saúde no nordeste brasileiro. Métodos: pesquisa social caracterizada como pesquisa participante. Foi realizado um Grupo Focal com nove gestantes que já tiveram outros filhos. Para as análises, a perspectiva das práticas discursivas e da Produção de Sentidos no Cotidiano foram trabalhadas. Resultados: foram produzidas as categorias: pré-natal, relação mãe-bebê, família, e dor/sofrimento. Considerações Finais: são inúmeros os benefícios da amamentação para a criança, a mulher, a família e a sociedade, porém é necessário que a mulher tenha acesso a um pré-natal e uma atenção ao puerpério qualificado para que ela se sinta amparada em uma perspectiva do cuidado integral.

Descritores: Saúde da Mulher; Aleitamento Materno; Atenção Básica; Cuidado Pré-Natal; Educação em Saúde.

\section{RESUMEN}

Objetivos: comprender los sentidos y las prácticas sobre la lactancia producidos por las mujeres acompañadas en el prenatal en una Unidad Básica de Salud en el nordeste brasileño. Métodos: investigación social caracterizada como investigación participante. Ha realizado un Grupo Focal con nueve gestantes que ya tuvieron otros hijos. Para los análisis, la perspectiva de las prácticas discursivas y Producción de Sentidos en el Cotidiano fueron trabajadas. Resultados: Han producido las categorías: prenatal, relación madre-bebé, familia, y dolor/sufrimiento. Consideraciones Finales: son innumerables los beneficios de la lactancia para el niño, la mujer, la familia y la sociedad, pero es necesario que la mujer tenga acceso a un prenatal y una atención al puerperio calificado para que ella se sienta amparada desde una perspectiva del puerperio calificado, cuidado integral.

Descriptores: Salud de la Mujer; Lactancia Materna; Atención Primaria de Salud; Atención Prenatal; Educación en Salud. 


\section{INTRODUCTION}

The human species is the only one among mammals in which breastfeeding, in addition to being biologically determined, is conditioned by social, economic, cultural, ethnic-racial, psychologi$\mathrm{cal}$, and behavioral factors. Breastfeeding is no longer a universal practice, often leading to divergences between the biological expectation of species, and culture. Some consequences of these divergences have already been observed, such as malnutrition and high infant mortality, especially in less developed areas ${ }^{(1)}$.

Human milk has a high biological constitution that includes all the nutrients essential to the development of the newborn ${ }^{(2)}$. The Ministry of Health $(\mathrm{MoH})$ recommends breastfeeding to be exclusive for at least the first six months because it is considered the most natural and desirable method of infant feeding with respect to the development of child's physiological, physical and psychological aspects ${ }^{(3)}$. Psychological aspects of breastfeeding are also related to the development of the individual and their affective and emotional condition. Furthermore, experiences in early childhood are extremely important in identity process construction of the individual as an adult $t^{(4)}$.

There was a time when breastfeeding was part of the socio-cultural context, women were breastfeeding because their mothers had breastfed and their grandparents too. This knowledge and custom was passed down from generation to generation without questioning the ability to breastfeed or the importance of breast milk ${ }^{(5)}$.

With the advent of industry and the insertion of women in the labor market, there has been a great change in the behavior of society in several aspects, including related to breastfeeding issue ${ }^{(6)}$. Many women value breastfeeding, but do not adopt it as an exclusive food during the first six months of life, as recommended by MoH due to changes in the social and political profile of women in today's society ${ }^{(5)}$.

In the last 35 years, many actions have been developed in Brazil in an attempt to recover breastfeeding, especially in hospitals, e.g., Joint Housing system standardization, Brazilian Standard for Food Marketing for Infants and Young (NBCAL - Norma Brasileira de Comercialização de Alimentos para Lactentes) approval, standards establishment for human milk banks functioning, Baby-Friendly Hospital Initiative (BFHI) implementation, and distribution interruption of formula in health services ${ }^{(7)}$. In 2013, through the Minister's Office/MoH Ordinance n. 1.920, the Amamenta e Alimenta Brasil strategy was instituted, aiming to reach Basic Health Units pregnant women and puerperas for a work of health education with the intention of encouraging breastfeeding and reducing the use of unhealthy food for the child ${ }^{(8)}$.

However, breastfeeding promotion strategies commonly practiced remain marked by the inability to deal with the ambivalence that is established for women between power and wanting to breastfeed the child. The hegemonic care model, which is vertical and imposed, proves incapable of responding to women demands in breastfeeding ${ }^{(9)}$.

According to Rea ${ }^{(10)}$, policies that sought to affirm over the years the importance of breastfeeding had a positive impact on the country development. However, according to the author, poorly performed pro-breastfeeding strategies can lead to the use of formula, bottle and/or other devices. It is necessary to listen and understand women and their difficulties with breastfeeding. This reguidance needs to involve health teams and intersectoral policies.
It is a challenge that requires a clinical and political effort for the need to encourage exclusive breastfeeding for six months. However, it should also observe and seek concrete intervention pregnant women and puerperas without interrupting breastfeeding until at least the second year of life. This should include Brazil's social and economic inequities with groups in special circumstances (HIV-positive mothers and families in emergency situations), the mother's working day and her mental health status.

Furthermore, this research sought to listen to a group of women and, from this listening, to make possible a knowledge construction that can contribute to work qualification and organization during prenatal care development in Primary Care, considering the phenomenon complexity and, above all, the need to incorporate breastfeeding contemporary aspects into the family dynamics and the women's life.

\section{OBJECTIVES}

To understand the meanings and practices on breastfeeding produced by women attending prenatal care at a Basic Health Unit in the Brazilian Northeast.

\section{METHODS}

\section{Ethical aspects}

This research was submitted to the Research Ethics Committee of Centro Universitário Cesmac and was only started after its approval. The research was conducted within ethical standards based on Resolution 466/12 guidelines of the Brazilian National Health Board (CNS - Conselho Nacional de Saúde/MoH) ${ }^{(11)}$.

\section{Theoretical-methodological framework}

The research was based on the circumscribed approximations of qualitative social research, especially with influences of Social Constructionism and adopted the perspective of Discursive Practices and Production of Meanings in Everyday Life as a guiding theoreticalmethodological framework that has as its bias the discussion about the use of language as "a form of action in the world"121. Some authors ${ }^{(13-15)}$ characterize Social Constructionism as a movement that assumes a constant critical position in the face of deterministic and unquestionable phenomena. This movement is especially concerned with how interactions occur between people, construction of the meanings of these relations and how they narrate the world and themselves, focusing on language implantation as knowledge production.

\section{Type of study}

This is a qualitative social research characterized as participant research.

\section{Methodological procedures}

\section{Study setting}

The research was carried out in a Basic Health Unit located in the Brazilian Northeast. The state has low social and economic 
indicators, with $47.4 \%$ of the population vulnerable to poverty ${ }^{(16)}$. The Unit counts on medicine, nursing, psychology, pharmacy, social service and speech therapy professionals that offer care in health programmatic actions form women, children and elders having pharmacy services, vaccines room, dressings and laboratory. In care for women, the following activities are performed: family planning, prenatal care, puerperium, pregnant women, and breastfeeding groups.

\section{Data source}

A total of 9 (nine) women from eighteen to forty years old, assisted by the unit's prenatal service, participated in this study. All participants belong to economic class " $E$ ", with low schooling level (06 incomplete elementary school and 03 complete elementary school). On occupational conditions, six (6) of them declared themselves to be unemployed, two (2) as domestic servants and one (1) as local supermarket cashier, and all nine (9) women declared to be brown. Women were invited to spontaneously participate in the study during one of the weekly meetings of the group performed at the Health Unit. The essential criterion to participate in the research was to have experienced breastfeeding in gestation or previous pregnancies. The meeting to hold the Focul Group (FG) took place on the appointed day and time, lasting 1 hour and 30 minutes. Women who agreed to participate in the research signed the FICT, as recommended by Resolution $466 / 12$ of $\mathrm{CNS}^{(11)}$.

\section{Collection and organization of data}

The FG technique was used to collect data, which is a quick, easy and practical way to get in touch with the population to be investigated ${ }^{(17)}$. In other words, it is a method to obtain understanding of participants regarding the research object, since it allows the development of spontaneous speech and allows the researcher to have access to communication and language of the group. A FG session was held with a mediator and an observer previously oriented to observation and reporting work. The questions that guided the group's conversation were: why breastfeeding? What made you decide to breastfeed? How do you organize your dailybreastfeeding? Can you tell us a bit about your breastfeeding experience? The speech was recorded during the meeting with women's consent. Subsequently statements were transcribed in full for data production and analysis. To ensure confidentiality and anonymity, women's names were replaced by colors.

\section{Data analysis}

The study worked with the use of audio full transcription, including all speeches and expressions communicated, that is, it was performed in a literal way, in order to preserve the original speech. A Map with Sequential Transcription was produced, the first material approximation to be analyzed that allows theme or category definition for the use of Dialogic Maps ${ }^{(18)}$. The Discursive Practices framework were worked and language meanings in use as social practice were adopted, as well as the performative contents and conditions of its production, socially and culturally located as elements for analysis ${ }^{(15-18)}$. Another Dialogical Map was produced with systematization: "Who speaks? What are you talking about? What themes emerged from these lines?", a strategy to make speeches visible and then articulate the sets of meanings present in linguistic repertoires used by women to talk about breastfeeding.

\section{RESULTS}

The four categories that guided the analysis and made it possible to give visibility to the dialogue present in the analyzed speeches were prenatal, mother-baby relationship, family and pain/suffering.

\section{Prenatal}

This study shows that practices to encourage breastfeeding during prenatal care are still insufficient. Guidance, for the most part, is centered on cognitive processes, with little space for relational and affective processes that accommodate the mother with her doubts and conflicts. There is no preparation to encourage and support women according to the specific needs of each of them who wish to breastfeed. Thus, when asked if during prenatal care someone had advised them about breastfeeding, Yellow and Blue responded:

He advised (quotation marks), so he said it was important, but did not say what it was I was going to do. He just said it was important for the baby's health, for the mother's health, all of this. (Yellow)

The physician used to say, "It's good to breastfeed for health, illness, milk is good, does not replace milk, do not give water," I always listened to that. (Blue)

Therefore, it can be seen that the conduct related to breastfeeding during prenatal care can and should be qualified to incorporate life stories and the specific context of women. When Yellow uses quotation marks feature to talk about her experience, one can see how much this guidance distances itself from her concerns and demands. Guidance on breastfeeding in prenatal care is undoubtedly very important, and new actions must be incorporated by health professionals in order to encourage breastfeeding. Embracement and extended clinical listening are tools that can build with women's strategies for transdisciplinary work that boost them for breastfeeding both in the nutritional aspect and in the bonding between the child, the mother and other familiar, and vicinal references.

\section{Mother-Baby Relationship}

From the child's birth, mothers go through a process of learning how to know/understand her language. In some cases, they are little oriented on how to handle the child's crying/behavior. Overall, they use artificial nozzles (pacifiers and/or bottle) or the introduction of teas and milk formulas, in order to calm and prevent the child from crying, as indicated Yellow and Blue:

She was a very crying girl. I tried to breastfeed her, but she only breastfed for up to four months. She was angry, when she was 
hungry she did not want to see the breast. I wanted her to breastfeed, but there was no way. Four months; she really did. Then, you did not, did you? She had to go start having milk. (Yellow)

Because my son cried a lot at night and she (grandmother from mother's side of family) fed him. (Blue)

There is a lack of preparation of the mother/family in dealing with the child's development and behavior due to lack of information or adequate guidance in prenatal care and in puerperium. Often in situations as signaled by Yellow and Blue, anxiety, fear, experience of building a new relationship interfere in the building of a healthy bond. To face these moments end up resorting to the use of strategies and tools that can negatively interfere with breastfeeding.

\section{Family}

Family support can positively influence breastfeeding. The care network made possible by the family can both facilitate the child's development and subsidize care processes. That is what Yellow tells us when reports:

And that's what I got, more with my mother, she always breastfeed and she said the best thing was to breastfeed, and that's what I got for myself. (Yellow)

However, there are also reports where family becomes a difficult agent for breastfeeding, unlike Yellow, Blue says:

However, for my mother, the day l left, she said: "Give milk to this boy, he only lives crying". Because, because of my mother, she already wanted to feed me the day l left the clinic. (Blue)

My mother came to help me, but in quotation marks, she did not know it, but it got in my way because my son was crying a lot at night and she fed me. He spent almost fifteen days without pooping. (Blue)

It is important not to generalize patterns of care and family functioning, but rather to recognize in the woman's own history what the best alternatives are to ensure extensive family support. The same happens with regard to the father contributions, who can exert positive or negative influence on maternity and lactation. Hence, when asked if they received support or had the contribution of their partners during breastfeeding, White reported that she had the support of her husband, according to her report:

I went to the dentist, I arrived with a very full breast, I slept with him pricked. Then my husband said, "White, let's resolve this! Put it out!" When he sucked, the milk dried. He saw my suffering and he was like that, he played and I said, "Do not touch, no!" It seemed like it was going to shock. Then my husband went and sucked it. (White)

It is evident how important the father's participation in breastfeeding is. Historically breastfeeding is a function of women. However, in order for her to develop this ability, it is necessary that several support repertoires are organized for this purpose. This involves the father in the domestic functions, the extended family for the organization of the relations in the resumption of work and other activities that require the presence of the same woman during the period of lactation.

\section{Pain and Suffering}

The negative factors related to breastfeeding were evidenced in some of the speeches in this study, which suggests a rethinking of the current breastfeeding promotion strategies, as reported by Yellow in relation to the first daughter:

I wanted her to suck the milk, but there was no way. Four months she really did. My breast was full, I had a fever, it was horrible, it was horrible. Then, it still did not work, right? She had to have formula. (Yellow)

Sometimes even wanting to breastfeed mothers interrupt the process, due to lack of support or adequate guidance offered by the health team or by the family. And they suffer from failure, because success in breastfeeding is often associated with the label of "good mothers." In her experience with her second daughter, Yellow reports:

Both times, my breast cracked, but I did not stop. When she cried to nurse, I looked at my breast and looked at her. I looked at my breast and looked at her. I say "Oh my god, but that's the way!" Then when she gave the first blow I would go up and back. The tear went up in my eyes, but I did not give up! Neither the first nor the second. (Yellow)

About the negative factors, Lilac stated:

I also breastfed, but my breast hurt a lot. It was horrible. But I loved, right?! Because the physician said she would heal later, when he was breastfeeding, he would heal. Then I always breastfed, I always had a good milk, I always had a lot of milk, and then he was sucking the milk until he was three years old. (Lilac)

One can see in these lines that there is an acceptance/overcoming of pain, a resignation perhaps, by "duty" or "wanting" to breastfeed. Which leads one to think whether this is due to the desire to breastfeed or the pressure established/imposed by society. It is noted in Lilac's speech that women face difficulties not only at the beginning of breastfeeding, but also at the end of it, when they wish to carry out weaning because the child is already old enough to eat other foods and/or the mother feel the need to wean the child. For, it seems, they lack adequate support and guidance also in this stage:

He just stopped breastfeeding, I think it's going to be about six, seven months. But it was complicated for him to stop breastfeeding. Oh my God! I tried everything for him to leave the breast. I put nail polish, I put that thing you apply in bruises. (Lilac)

In another speech, Pink shows the inability to deal with the situation, perhaps for lack of information or proper care during puerperium. This situation is still quite common, since the 
professional's conduct, since its formation, is centered on protocols of procedures and with little openness to doubts, yearnings, anxieties and anxieties during prenatal care:

I came home the first week, I fed him right. In the second week, I started to have fever, a lot of fever, a lot of fever, a lot of pain in my body. I had a lot of headache, a lot of fever, I was shaken all over in bed. Then I had to stop breastfeeding him, because when I started to have a fever, and I gave him, then he had a fever too. (Pink)

According to Green, difficulties arose at the time of negotiating with the baby the feeding time. This moment demands a lot from the mother, as there is a radical change, in the majority of the times, in the daily routine and dynamics:

So she just did not like it when she woke up at three o'clock in the morning. Then, as she slept in her cradle, three o'clock in the morning sharp she woke up. Then I would put her to my bed. (Green)

Breastfeeding is a process susceptible to multiple influences; and family members, the media, and health professionals are responsible for a good deal of interference with the decision to breastfeed. It is thought that in the approach with nursing mothers, health professionals need to be receptive and sensitive to listening to these women, in addition to respecting their beliefs related to breastfeeding.

\section{DISCUSSION}

The guidelines given to women during prenatal care are essential for a healthy pregnancy, as well as for the maintenance of breastfeeding ${ }^{(19)}$. However, this study pointed to the need for this guidance to be guided by the experiences, values, desires, fears, expectations and, above all, the women's family support network. These educational actions during pregnancy and puerperal cycle make it possible to positively experience the experience of childbirth, to avoid complications in the puerperium, to take care of the child more safely and to succeed in breastfeeding ${ }^{(20)}$. The monitoring of this course is an important tool to access the unique universe of the family and the mother, it must be explored by the health team at its highest quality. It is in the opening for the conversation that the prenatal one qualifies for the production of the enlarged clinic. The link between health team and woman should be the guiding line so that the clinical protocols can be resolutive.

Education and training of women during prenatal care greatly contribute to increasing ability, safety and confidence, helping to ensure the success of breastfeeding ${ }^{(21)}$. Only information is often not enough for women to have motivation and success in breastfeeding, since the information ends up being cognitive and does not necessarily imply accessing the affective or desire pathways ${ }^{(22)}$. Generally, women and families have access to basic information about the importance of breastfeeding and the positive effects of breastfeeding on the child's life, but she still feels insecure and anxious about not meeting breastfeeding demands.

It is necessary to trigger other ways than the prescriptive information. Establishing a dialogic relationship in the production of care with women allows the dimension of affection to be achieved and, thus, a comprehensive approach facilitates the reception of the various demands that arise in the prenatal and puerperium, such as anxiety and fear.

Primary Care plays an important role in strengthening actions to promote, protect and support breastfeeding, thanks mainly to the perspective of comprehensiveness, the development of transdisciplinary work and longitudinal and territorial care. For $\mathrm{MoH}$, breastfeeding saves many children a year, promoting and preventing infections, and exclusive breastfeeding is important from a nutritional and psycho-affective point of view ${ }^{(7)}$.

There are many benefits of breastfeeding for children, women, family, and society. In order to be successful in this process, women need to be well assisted and supported by the health and family team, since innumerable factors are involved in the difficulty in breastfeeding or early weaning, among which are the mothers' lack of knowledge about breastfeeding, as well as the social, political and cultural aspects that involve breastfeeding $^{(23)}$. Among the major influences on breastfeeding are previous experiences and the emotional state of the nurse, as well as the family (especially the father and the grandmother), and health professionals, both as transmitters of myths and beliefs and as a source of encouragement/support ${ }^{(24)}$.

Some maternal difficulties during breastfeeding may be related, directly or indirectly, to the child's father, especially when he has a feeling of repulsion towards breastfeeding ${ }^{(25-26)}$. It is important that breastfeeding incentive programs include the father in educational and guidance activities and that health professionals listen and clarify their desires and doubts, making the father an incentive and a point of support for the mother during lactation, thus having a positive influence on this process ${ }^{(26)}$. Therefore, it is necessary to inform the father or other person who is in this affective relationship with the woman about the advantages of lactation and its meaning, and that this educational process should begin in childhood, helping the success and maintenance of breastfeeding ${ }^{(26-27)}$.

While acknowledging the centrality of women in promoting breastfeeding, programs do not always consider women's perceptions about breastfeeding and its influence on daily life. It is necessary to rethink the current model of breastfeeding incentive adopted by health policies, in which mothers are intensely responsible and at the same time excluded from breastfeeding as women, and now are active subjects, for having the responsibility to breastfeed because her feelings and desires are not considered in this process ${ }^{(28)}$. As already mentioned, prenatal care needs to incorporate these issues so as not to distance oneself from the daily lives of doubts, fears and anxieties of women and families, and to remain hostage to biomedical protocols.

The speech released by the media in favor of breastfeeding influences the construction of an idealization about breastfeeding, besides being a socially determined practice as an act of love for the child ${ }^{(29)}$. Moreover, it is necessary for women to feel safe and welcomed by their concrete issues of pain, suffering and learning regarding maternity and, above all, that the health team is prepared for the contemporary breastfeeding demands, new family dynamics and reorganization of work in the development and care during prenatal and puerperium, which has incorporated a diversity of professional knowledge and practices. 


\section{Study limitations}

As limitations, authors acknowledge the need to develop new studies that can make the perspectives of parents and health professionals more visible, thus increasing the capacity to understand the phenomenon complexity involving breastfeeding relationship, as well as research that seek to understand breastfeeding from a gender perspective and from the new family arrangements.

\section{Contributions to Nursing, Health or Public Policies}

It is expected to contribute to a health care construction that considers meanings and practices about breastfeeding from women's speech and experiences. It is necessary to insert the production of light and relational technologies in nursing protocols, and, above all, in work organization to care for women in prenatal care and puerperium. In Primary Care, it is fundamental, for the care model change, that bond is valued as a strategy that also produces resolutiveness.

\section{FINAL CONSIDERATIONS}

The conduction of this study allowed an approximation on breastfeeding meanings and practice in the woman's perspective. The listening of their affections, feelings and restlessness during breastfeeding are presented as the best guiding axis to carry out an educational approach during prenatal and puerperium. It was understood that women understand the value of breastfeeding as beneficial for the baby's health. However, this relationship is also crossed by fear and insecurity. The importance of the inclusion of grandparents and parents of children in educational processes on breastfeeding was considered, considering the strong influence they have on the woman's decision to breastfeed and/or in this practice maintenance.

It is in Primary Care that the pregnant woman, the puerperal and the infant are in contact with the Brazilian Unified Health System (SUS - Sistema Único de Saúde), and that professionals in this area should be able to guide, support and encourage breastfeeding. Thus, complications similar to those experienced by participants of this research during breastfeeding and that may lead to early weaning could be prevented if they were given adequate guidance in health units. Investing in Permanent Education and professional qualification is a responsibility of SUS and managers together with training institutions should contribute to this change in comprehensive care for women.

Actions aimed at the promotion of breastfeeding bring only the attempt to convince women to breastfeed, followed by the hygienist model that aims, above all, to reduce infant mortality. Moreover, it is not only a matter of guiding or helping women in the choice of breastfeeding, but of making every effort to embrace her fully, as well as offering care and support also to the time of weaning.

Investment in active methodologies of care production and organization valuation of work, in a multidisciplinary perspective, is presented as a strategy that can increasingly bring women, family, community, and team in prenatal care and puerperium qualification in Primary Care.

\section{REFERENCES}

1. Moura ERBB, Florentino ECL, Bezerra MEB, Machado ALG, et al. Investigação dos fatores sociais que interferem na duração do aleitamento materno exclusivo. Revinter [Internet]. 2015 [cited 2018 Jan 17];8(2):94-116. Available from: http://revistarevinter.com.br/minhas-revistas/2015/v-8-n-22015-volume-8-numero-2-junho-de-2015-sao-paulo/269-investigacao-dos-fatores-sociais-que-interferem-na-duracao-do-aleitamento-maternoexclusivo/file

2. Genovez CB, Uchimura TT, Santana R, Nishida FS. Banco de leite humano: uma análise entre doadoras adultas e adolescentes. Acta Sci, Health Sci. 2011;33(2):211-8. doi: 10.4025/actascihealthsci.v33i2.8266

3. Ministério da Saúde (BR). Secretaria de Atenção à Saúde. Promovendo o aleitamento materno [Internet]. Brasília: Ministério da Saúde; 2007 [cited 2018 Jan 17]. Available from: http://www.redeblh.fiocruz.br/media/albam.pdf

4. Antunes LS, Antunes LAA, Corvino MPF, Maia LC. Amamentação natural como fonte de prevenção em saúde. Ciênc Saúde Colet. 2018;13(1):103-9. doi: 10.1590/S1413-81232008000100015

5. Bosi MLM, Machado MT. Amamentação: um resgate histórico. Caderno Esp: Escola de Saúde Pública do Ceará [Internet]. 2005 [cited 2018 Jan 17];1(1). Available from: http://www.aleitamento.com.br/upload\%5Carquivos\%5Carquivo1_1688.pdf

6. Pereira e Moura L, Oliveira JM, Noronha DD, Torres JDRV, Oliveira KCD, Mariza Alves Barbosa Teles MAB. Percepção de mães cadastradas em uma estratégia saúde da família sobre aleitamento materno exclusivo. Rev Enferm UFPE. 2017;11(3):1403-9. doi: 10.5205/ reuol.10263-91568-1-RV.1103sup201712

7. Ministério da Saúde (BR). Secretaria de Atenção à Saúde. Departamento de Informática do SUS (DATASUS). Indicadores de Mortalidade: razão de mortalidade materna [Internet]. Brasília: Ministério da Saúde; 2012 [cited 2018 Jan 17]. Available from: http://tabnet.datasus.gov. br/cgi/idb2012/C03b.htm

8. Ministério da Saúde (BR). Gabinete do Ministro. Portaria no 1.920. Institui a Estratégia Nacional para Promoção do Aleitamento Materno e Alimentação Complementar Saudável no Sistema Único de Saúde (SUS) - Estratégia Amamenta e Alimenta Brasil [Internet]. Brasília: Ministério da Saúde; 2013 [cited 2018 Jan 17]. Available from: http://bvsms.saude.gov.br/bvs/saudelegis/gm/2013/prt1920_05_09_2013.html

9. Almeida JAG, Gomes R. Amamentação: um híbrido natureza-cultura. Rev Latino-Am Enfermagem. 1998;6(3):71-6. doi: 10.1590/ S0104-11691998000300009 
10. Rea MF. Reflexões sobre a amamentação no Brasil: de como passamos a 10 meses de duração. Cad Saúde Pública. 19(Supl. 1):S37-45. doi: $10.1590 / 50102-311 \times 2003000700005$

11. Ministério da Saúde (BR). Conselho Nacional de Saúde. Resolução n 466, de 12 de dezembro de 2012. Aprova as diretrizes e normas regulamentadoras de pesquisas envolvendo seres humanos e revoga as Resoluções CNS nos. 196/96, 303/2000 e 404/2008 [Internet]. Brasília: Ministério da Saúde; 2012 [cited 2018 Jan 17]. Available from: http://bvsms.saude.gov.br/bvs/saudelegis/cns/2013/ res0466_12_12_2012.html

12. Spink PK. O pesquisador conversador no cotidiano. Psicol Soc. 2008;20(spe):70-7. doi: 10.1590/S0102-71822008000400010

13. Castañon GA. Construcionismo social: uma crítica epistemológica. Temas Psicol [Internet]. 2004 [cited 2018 Jan 17];12(1):67-81. Available from: http://pepsic.bvsalud.org/pdf/tp/v12n1/v12n1a08.pdf

14. Resera EF, Japur M. Problema e mudança em terapia de grupo: descrições construcionistas sociais. Psic: Teor Pesq. 2005;21 (1):33-41. doi: $10.1590 /$ S0102-37722005000100006

15. Méllo RP, Silva AA, Lima MLC, Di Paolo AF. Construcionismo, Práticas Discursivas e possibilidades de pesquisa em Psicologia Social. Psicol Soc. 2007;19(3):26-32. doi: 10.1590/S0102-71822007000300005

16. Instituto Brasileiro de Geografia e Estatística (IBGE). Síntese de indicadores sociais: uma análise das condições de vida da população brasileira: 2017 [Internet]. Rio de Janeiro: IBGE; 2017 [cited 2018 Jan 17]. Available from: https://biblioteca.ibge.gov.br/visualizacao/livros/liv101459.pdf

17. Gui RT. Grupo focal em pesquisa qualitativa aplicada: intersubjetividade e construção de sentido. Rev Psicol, Organ Trab [Internet]. 2003 [cited 2018 Jan 17];3(1):135-59. Available from: http://pepsic.bvsalud.org/scielo.php?script=sci_arttext\&pid=\$1984-66572003000100007

18. Spink MJ. Práticas discursivas e produção de sentidos no cotidiano: aproximações teóricas e metodológicas. São Paulo: Cortez; 1999.

19. Silva KMS, Goetz ER, Santos MVJ. Aleitamento materno: conhecimento das gestantes sobre a importância da amamentação na Estratégia de Saúde da Família. RBCS. 2017;21(2):111-8. doi: 10.4034/RBCS.2017.21.02.02

20. Lima PFS, Santos CN, Silva MV, Lima Júnior AA. A atuação do enfermeiro na educação em saúde com ênfase no apoio a amamentação exclusiva até os seis meses de idade. Rev Saúde UNG-Ser [Internet]. 2017 [cited 2018 Jan 17];10(1):45. Available from: http://revistas.ung.br/ index.php/saude/article/view/2633

21. Vargas GS, Alves VH, Rodrigues DP, Branco MBLR, Souza RMP, Guerra JVV, et al. Atuação dos profissionais de saúde da estratégia saúde da família: promoção da prática do aleitamento materno. Rev Baiana Enferm. 2016;30(2):1-9. doi: 10.18471/rbe.v30i2.14848

22. Visitin AB, Primo CC, Amorim MHC, Leite FMC, et al. Avaliação do conhecimento de puérperas acerca da amamentação. Enferm Foco. 2016 [cited 2018 Jan 17];6(1/4):12-6. Available from: http://revista.portalcofen.gov.br/index.php/enfermagem/article/view/570/252

23. Alencar AP, Nascimento GL, Lira PF, Fonseca FLA, Fonseca RLA, Alves BCA, et al. Principais causas do desmame precoce em uma estratégia de saúde da família. Saúde Meio Ambient.: Rev Interdisciplin [Internet]. 2017 [cited 2018 Jan 17];6(2):65-76. Available from: http://www. periodicos.unc.br/index.php/sma/article/view/1456/794

24. Martins RMC, Montrone AVG. O aprendizado entre mulheres da família sobre amamentação e os cuidados com o bebê: contribuições para atuação de profissionais de saúde. Rev APS. 2017;20(1):21-9. doi: 10.34019/1809-8363.2017.v20.15942

25. Piazzalunga CRC, Lamounier JÁ. O contexto atual do pai na amamentação: uma abordagem qualitativa. Rev Med Minas Gerais [Internet]. 2011 [cited 2018 Jan 17];20(1):133-41. Available from: http://rmmg.org/artigo/detalhes/185

26. Lima JP, Cazola LHO, Pícoli RP. A participação do pai no processo de amamentação. Cogitare Enferm. 2017;22(1):1-7. doi: 10.5380/ce.v22i1.47846

27. Dias RB, Boery RNSO, Vilela ABA. Conhecimento de enfermeiras e estratégias de incentivo da participação familiar na amamentação. Ciênc Saúde Colet. 2016;21(8):2527-36. doi: 10.1590/1413-81232015218.08942015

28. Dodou HD, Oliveira TDA, Oriá MOB, Rodrigues DP, Pinheiro PNC, Luna IT. Educational practices of nursing in the puerperium: social representations of puerperal mothers. Rev Bras Enferm [Internet]. 2017;70(6):1250-8. doi: 10.1590/0034-7167-2016-0136

29. Moreira LA, Velasco e Cruz N, Linhares FMP, Guedes TG, Martins FDP, Pontes CM. Support to woman/nourisher in the advertising pieces of the World Breastfeeding Week. Rev Bras Enferm [Internet]. 2017;70(1):55-64. doi: 10.1590/0034-7167-2016-0376 